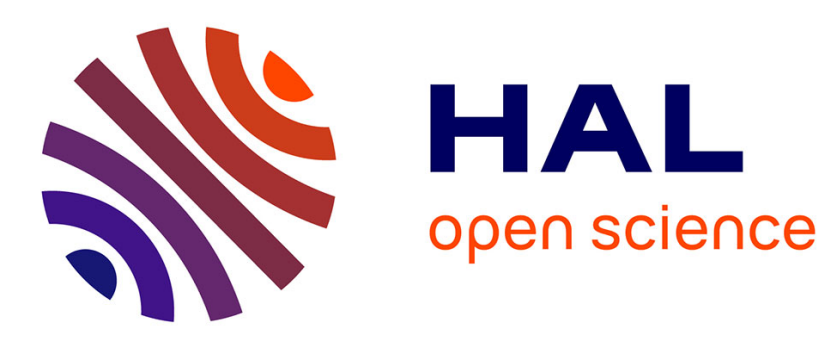

\title{
Liver scalloping: Pseudomyxoma peritonei liver compression
}

K. Allart, C. Sabbagh, J.-M. Regimbeau

\section{To cite this version:}

K. Allart, C. Sabbagh, J.-M. Regimbeau. Liver scalloping: Pseudomyxoma peritonei liver compression. Journal of Visceral Surgery, 2019, 156, pp.75 - 76. 10.1016/j.jviscsurg.2018.09.001 . hal-03486563

\section{HAL Id: hal-03486563 https://hal.science/hal-03486563}

Submitted on 20 Dec 2021

HAL is a multi-disciplinary open access archive for the deposit and dissemination of scientific research documents, whether they are published or not. The documents may come from teaching and research institutions in France or abroad, or from public or private research centers.
L'archive ouverte pluridisciplinaire HAL, est destinée au dépôt et à la diffusion de documents scientifiques de niveau recherche, publiés ou non, émanant des établissements d'enseignement et de recherche français ou étrangers, des laboratoires publics ou privés.

\section{다)(1) $\$$}

Distributed under a Creative Commons Attribution - NonCommercial| 4.0 International 


\section{Liver scalloping: pseudomyxoma peritonei liver compression}

Kevin Allart $\mathrm{MD}^{1,2}$, Charles Sabbagh MD, $\mathrm{PhD}^{1,2}$, Jean-Marc Regimbeau MD, $\mathrm{PhD}^{1,2,3}$

1. Service de chirurgie digestive, Centre hospitalier Universtaire Amiens, Avenue René Laennec, F-80054 Amiens Cedex 01, France

2. Université Picardie Jules Verne, 1 Chemin du Thil, 80000 Amiens Cedex 01, France

3. SSPC (Simplifications des Soins Patients Chirurgicaux Complexes, or Simplication of care of complex surgical patients), Unité de recherché clinique, Université Picardie Jules vernes, Amiens, France

Running Title: Scalloping hépatique

\section{Correspondant}

Professeur J.-M. Regimbeau

Service de chirurgie digestive, Hôpital Sud, CHU d'Amiens, Avenue René Laennec, F-80054 Amiens Cedex 01, France

Phone: +33 322668301

Fax: +33 322668680

E-mail: regimbeau.jean-marc@chu-amiens.fr

Keywords: Scalloping, Pseudomyxome, Peritoine, CHIP, Mucocèle, . 


\section{Abstract}

Pseudomyxoma peritonei is a rare tumor characterized by the presence of mucous disseminated throughout the peritoneal cavity generally arising from the rupture of an appendicular mucocele. Liver scalloping is a highly suggestive image of pseudomyxoma and corresponds to the indentation of the liver compressed by the gelatinous mucin.

Pseudomyxoma peritonei (PMP) is rare tumor characterized by the dissemination of mucous in the peritoneal cavity excreted by adenomucinous tumor cells that have invaded the peritoneum. This invasion is the final stage of a process that starts by the rupture of a localized mucinous tumor. Tumors giving rise to PMP are generally appendicular mucoceles, more rarely ovarian mucinous cystadenoma and cystadenocarcinoma (1).

The clinical course is slow. The tumor is generally discovered on imagine proposed to search for the origin of an appendicular syndrome or because of an increased abdominal circumference related to an excessive amount of mucine excreted into the abdominal cavity. Tumor markers (CA19-9 and CEA) are generally elevated.

Radiological elements suggestive of pseudomyxoma include well-designed liver scalloping due to extrinsic compression of the liver by the gelatinous mass, partitioning and the peritoneal effusion, together with curvilinear calcifications (2). It is noteworthy that this scalloping can be observed even when the excreted volume is very low (3). Computed tomography (CT) and magnetic resonance imaging (MRI) of the abdomen are needed for the preoperative assessment of resectability. MRI any provide more information than CT for assessing the degree of bowel involvement $(4,5)$.

The gold standard treatment for PMP in a curative situation is cytoreductive surgery combined with hyperthermic intraperitoneal chemotherapy $(6,7)$. In a palliative situation, tumor debulking may be proposed. 


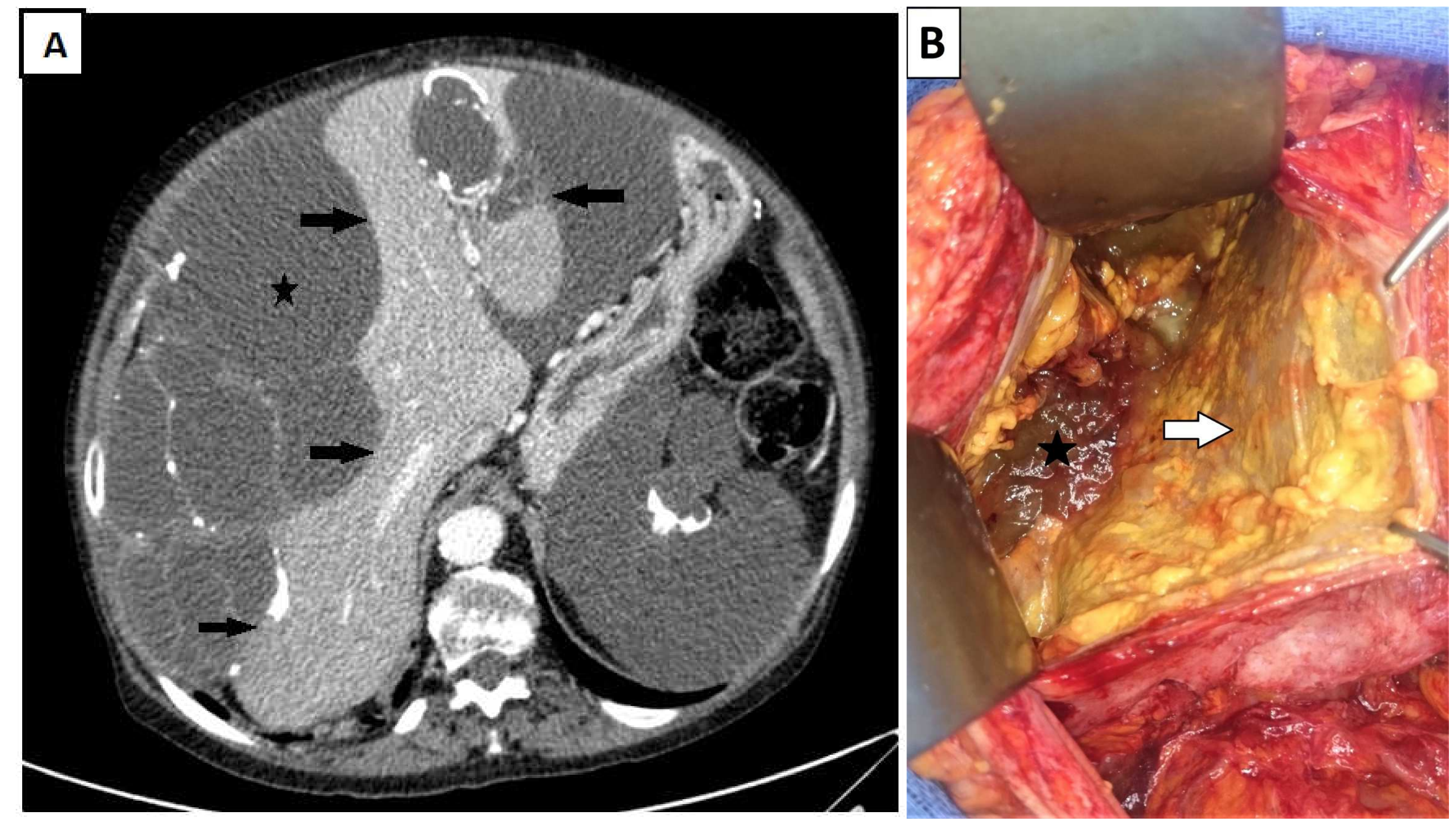

